\title{
Surface Water Modeling Using an EPA Computer Code for Tritiated Waste Water Discharge from the heavy Water Facility
}

by

K. F. Chen

Westinghouse Savannah River Company

Savannah River Site

Aiken, South Carolina 29808

\section{MASTER 8}

CHTRIBUTION OF HAS DOWHET IS UNLIMITED

\section{DOE Contract No. DE-AC09-96SR18500}

This paper was prepared in connection with work done under the above contract number with the U. S. Department of Energy. By acceptance of this paper, the publisher and/or recipient acknowledges the U.S. Government's right to retain a nonexclusive, royalty-free license in and to any copyright covering this paper, along with the right to reproduce and to authorize others to reproduce all or part of the copyrighted paper. 
WSRC-TR-98-00230

June 1998

WSRC-TR-98-00230 (U)

\section{Surface Water Modeling Using an EPA Computer Code for Tritiated Waste Water Discharges from the Heavy Water Facility (U)}

Kuo-Fu Chen

Savannah River Technology Center

RECEIVED

SEP 241998

Q.STI

Publication Date: June 1998

$\begin{gathered}\text { DOES NOT CONTAIN } \\ \text { UNCLASSIFIED CONTROLLED } \\ \text { NUCLEAR INFORMATION }\end{gathered}$
ADC \&
Reviewing
Date: $\quad 6-23-98$.

Westinghouse Savannah River Company Savannah River Site Aiken, SC 29808

This document was prepared in connection with work done under Contract No. DE-AC09-96SR18500 with the U. S. Department of Energy 


\section{DISCLAIMER}

This report was prepared as an account of work sponsored by an agency of the United States Government. Neither the United States Government nor any agency thereof, nor any of their employees, makes any warranty, express or implied, or assumes any legal liability or responsibility for the accuracy, completeness, or usefulness of any information, apparatus, product, or process disclosed, or represents that its use would not infringe privately owned rights. Reference herein to any specific commercial product, process, or service by trade name, trademark, manufacturer, or otherwise does not necessarily constitute or imply its endorsement, recommendation, or favoring by the United States Government or any agency thereof. The views and opinions of authors expressed herein do not necessarily state or reflect those of the United States Government or any agency thereof.

This report has been reproduced directly from the best available copy.

Available to DOE and DOE contractors from the Office of Scientific and Technical Information, P.O. Box 62, Oak Ridge, TN 37831; prices available from (615) 576-8401.

Available to the public from the National Technical Information Service, U.S. Department of Commerce, 5285 Port Royal Road, Springfield, VA 22161. 


\section{DISCLAIMER}

Portions of this document may be illegible in electronic image products. Images are produced from the best available original document. 
WSRC-TR-98-00230

June 1998

DOCUMENT:

TITLE:
WSRC-TR-98-00230

Surface Water Modeling Using an EPA Computer Code for Tritiated Waste Water Discharges from the Heavy Water Facility (U)

TASK:

TECHNICAL REVIEW

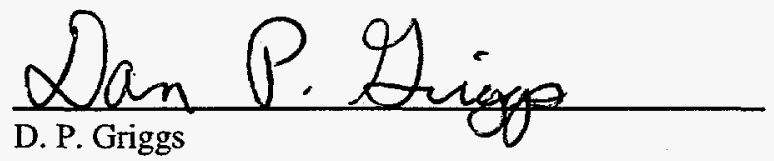

Date: $6 / 22 / 98$

SRTC/Measurement Technology Department/Nonproliferation Technologies Section

APPROVALS

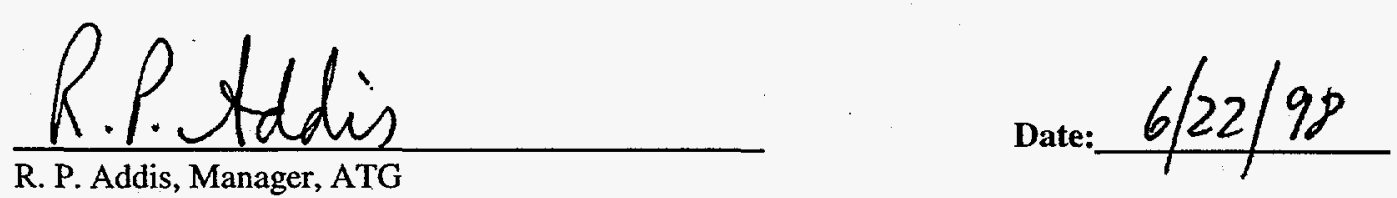

SRTC/Measurement Technology Department/Nonproliferation Technologies Section

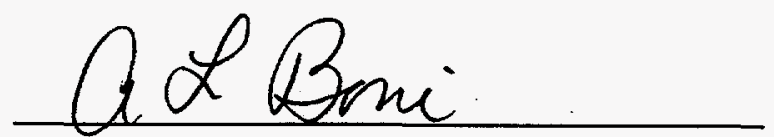

Date: $6-23-98$

A. L. Bon, Manager

SRTC/Measurement Technology Department/Nonproliferation Technologies Section

iii 
(Blank Page) 


\section{ABSTRACT}

Tritium releases from the D-Area Heavy Water Facilities to the Savannah River have been analyzed. The U.S. EPA WASP5 computer code was used to simulate surface water transport for tritium releases from the D-Area Drum Wash, Rework, and DW facilities. The WASP5 model was qualified with the 1993 tritium measurements at U.S. Highway 301. At the maximum tritiated waste water concentrations, the calculated tritium concentration in the Savannah River at U.S. Highway 301 due to concurrent releases from D-Area Heavy Water Facilities varies from 5.9 to $18.0 \mathrm{pCi} / \mathrm{ml}$ as a function of the operation conditions of these facilities. The calculated concentration becomes the lowest when the batch releases method for the Drum Wash Waste Tanks is adopted. 
WSRC-TR-98-00230

June 1998

(Blank Page) 
WSRC-TR-98-00230

June 1998

TABLE OF CONTENTS

1. SUMMARY

2. INTRODUCTION

3. WASP5 MODEL

4. MODEL QUALIFICATION

5. CALCULATIONS

3

6. CONCLUSIONS

7. REFERENCES 


\section{LIST OF TABLES}

Table 1. Specified Input Conditions $\quad 8$

Table 2. Estimated Tritium Releases in SRS Streams and the Savannah River 9

Table 3. WASP5 Calculations of Peak Tritium Concentrations in the Savannah River at U.S. Highway 301 due to Tritiated Liquid Waste Releases from the D-Area Heavy Water Facilities 


\section{LIST OF FIGURES}

Figure 1. Savannah River $\quad 14$

Figure 2. Beaver Dam Creek $\quad 15$

Figure 3. WASP5 Calculations of Tritium Concentrations in the Savannah River at U.S. Highway 301, due to D-Area Drum Wash Waste Tanks Releases

Figure 4. WASP5 Calculations of Tritium Concentrations in the Savannah River at U.S. Highway 301 due to D-Area Drum Wash Waste Tanks Releases

Figure 5. WASP5 Calculations of Tritium Concentrations in the Savannah River at U.S. Highway 301 due to D-Area Rework Distillate Tanks Releases

Figure 6. WASP5 Calculations of Tritium Concentrations in the Savannah River at U.S. Highway 301 due to D-Area DuPont Water Distillate Tanks Releases

Figure 7. WASP5 Calculations of Tritium Concentrations in the Savannah River at U.S. Highway 301 due to Concurrent Releases from the D-Area Heavy Water Facilities

Figure 8. WASP5 Calculations of Tritium Concentrations in the Savannah River at U.S. Highway 301 due to Concurrent Releases from the D-Area Heavy Water Facilities 
WSRC-TR-98-00230

June 1998

(Blank Page) 


\section{SUMMARY}

Tritium releases from the D-Area Heavy Water Facilities to the Savannah River have been analyzed. The U.S. EPA WASP5 computer code was used to simulate surface water transport for tritium releases from the D-Area Drum Wash, Rework, and DW facilities. The WASP5 model was qualified with the 1993 tritium measurements at U.S. Highway 301.

At the maximum tritiated waste water concentrations, the calculated tritium concentration in the Savannah River at U.S. Highway 301 due to concurrent releases from D-Area Heavy Water Facilities varies from 5.9 to $18.0 \mathrm{pCi} / \mathrm{ml}$ as a function of the operation conditions of these facilities. The calculated concentration becomes the lowest when the batch releases method for the Drum Wash Waste Tanks is adopted.

\section{INTRODUCTION}

The limits for tritiated waste water batch releases from D-Area Heavy Water facilities are based on predicted tritium concentrations in Savannah River at the U.S. Highway 301 bridge $[1,2]$. The bases for these limits need to be re-evaluated for the following reasons:

i. The assumptions for aqueous release periods and tritium concentrations used to develop the limits are inconsistent with actual conditions.

ii. Identification of release points is inconsistent within Reference [2].

iii. The limits are based on a single worst-case release scenario from four SRS facilities. There are total curie limits for individual releases but there was no evaluation for locations that have frequent releases nor are there explicit limits placed on discharge intervals.

The existing limits, as they are currently applied, could prevent concurrent operation of the Heavy Water Rework (RW), DuPont Water (DW) and Drum Washing facilities. The Environmental Compliance group of EXFAC \& RFS Division has requested ETS/SRTC to reevaluate the limits bases using validated modeling techniques [3]. Table 1 [3] lists the specified input conditions for this evaluation.

\section{WASP5 MODEL}

River Geometry

WASP5 [4] was used to model both the Savannah River and Beaver Dam Creek systems. 
WASP5 is a computer code developed by the EPA to model stream/river systems and to provide predictions of pollutant concentrations and water qualities in surface water systems.

Figure 1 shows the computer model for the Savannah River. This model extends from River Mile 168 (about 16.2 river miles upstream from the confluence with Beaver Dam Creek) to River Mile 16 (about 13 river miles downstream from Port Wentworth). To provide adequate detail for prediction of transient releases, the river was divided into 489 segments with a segment length of $500 \mathrm{~m}$ ( $0.31 \mathrm{mile})$. An average cross-section of 139 $\mathrm{m}^{2}\left(1500 \mathrm{ft}^{2}\right)$ was used for the river model.

Figure 2 shows the model for Beaver Dam Creek. This model covers a distance of 5.54 $\mathrm{km}$ (3.44 miles), starting above the D-Area outfall and extending to the Savannah River. Beaver Dam Creek was divided into 11 segments with a segment length of $500 \mathrm{~m}(0.31$ mile) and an average cross section of $5.94 \mathrm{~m}^{2}\left(63.94 \mathrm{ft}^{2}\right)$.

\section{MODEL QUALIFICATION}

The WASP5 model was qualified by comparing predicted tritium concentrations to measured tritium concentrations at U.S. Highway 301, about 20 miles down river from SRS. Tritium concentration measurements were obtained from Reference 5, as described in the following section.

\section{Tritium Concentration Data}

The average measured tritium concentration at the U.S. Highway 301 bridge for 1993 was $1.24 \pm 0.46 \mathrm{pCi} / \mathrm{ml}$ [Table 24 of Reference 5]. The measured tritium concentrations at U.S. Highway 301 include contributions from all upstream tritium releases. This section presents the method used to estimate the tritium concentration that would be measured at U.S. Highway 301 if only the tritium released from D-Area was considered.

Sources of tritium releases in SRS streams and the Savannah River are documented in Reference 5 and listed in Table 2. Table 2 shows that the tritium released from D-Area for 1993 accounted for $499 \mathrm{Ci}$. The total tritium released to Savannah River including direct releases and migration for 1993 was $12,700 \mathrm{Ci}$. Thus, D-Area contributed about $3.9 \%$ of the total tritium released to Savannah River and detected at U.S. Highway 301. The adjusted tritium concentration is $0.048 \pm 0.018 \mathrm{pCi} / \mathrm{ml}$, which would be measured at U.S. Highway 301 if only the tritium released from the D-Area was counted.

WASP5 Simulations for 1993 Tritium Measurements

WASP5 was used to simulate the surface water transport of tritium released from D-Area 
and to calculate the tritium concentration at U.S. Highway 301. The input data required by WASP5 include tritium release rates (Ci/day) from D-Area and the flow rates $\left(\mathrm{m}^{3} / \mathrm{s}\right.$ ) of Beaver Dam Creek and the Savannah River. The D-Area release rates ( $\mathrm{Ci} / \mathrm{yr}$ ) for 1993 listed in Table 2 were converted to $\mathrm{Ci} /$ day. The annual averaged Savannah River flow rate of $12,218.67 \mathrm{ft}^{3} / \mathrm{s}\left(345.99 \mathrm{~m}^{3} / \mathrm{s}\right)$ and the annual averaged Beaver Dam Creek flow of $77.85 \mathrm{ft}^{3} / \mathrm{s}\left(2.20 \mathrm{~m}^{3} / \mathrm{s}\right)$ were obtained from References [6] and [7]. The calculated tritium concentration contributed by D-Area at Highway 301 is $0.045 \mathrm{pCi} / \mathrm{ml}$. The measured tritium concentration contributed by $\mathrm{D}$-Area is $0.048 \pm 0.018 \mathrm{pCi} / \mathrm{ml}$. Thus, the calculated tritium concentration at Highway 301 is within the measurement variation.

\section{CALCULATIONS}

Eighteen (18) cases, listed in Table 3, were analyzed to simulate individual facility tritiated waste water releases and concurrent releases. Flows used for calculations are $5000 \mathrm{cfs}$ for the Savannah River and $31 \mathrm{cfs}$ for the Beaver Dam Creek. The operation conditions simulated for the facilities are based on the requirements specified by the Technical Assistance Request [3].

\section{Discharge from Drum Wash Waste Tank}

Tritiated waste water is released from the Drum Wash Waste Tanks twice per month. The inventory of each of the Drum Wash Tanks is 16000 gallon. Thus, to empty a tank, it takes 3200 minutes for a release rate of $5 \mathrm{gpm}$ and 1600 minutes for a release rate of 10 gpm. The maximum tritium concentration in the waste water is $3.5 \mu \mathrm{Ci} / \mathrm{ml}$ and the nominal tritium concentration is $1.25 \mu \mathrm{Ci} / \mathrm{ml}$. Six (6) discharge scenarios were simulated. Results of the computer simulations are tabulated in Table 3 and shown by Figures 3 and 4 . The calculations show that the downstream tritium concentrations are proportional to the discharge waste water concentrations. The calculations also show that the calculated Savannah River tritium concentrations depend on the release rate and the release duration. At a release rate of $10 \mathrm{gpm}$ of $3.5 \mu \mathrm{Ci} / \mathrm{ml}$ tritiated waste water and a release duration of 1600 minutes, the calculated tritium concentration in the Savannah River at U.S. Highway 301 is $15.5 \mathrm{pCi} / \mathrm{ml}$. This concentration drops to $2.8 \mathrm{pCi} / \mathrm{ml}$ when the Drum Wash Waste Tanks release rate is $5 \mathrm{gpm}$ of $1.25 \mu \mathrm{Ci} / \mathrm{ml}$ tritiated waste water and the release duration is 3200 minutes.

\section{Discharge from Rework Distillate Tanks}

The Rework Distillate Tanks are discharged up to six (6) times per day. The release rate is $10 \mathrm{gpm}$ and the release duration is 13 minutes. The maximum tritium concentration of the waste water is $10 \mu \mathrm{Ci} / \mathrm{ml}$. The nominal tritium concentration of the waste water is less than $5 \mu \mathrm{Ci} / \mathrm{ml}$. Case 7 and 8 simulate Rework Distillate Tanks operating with one 
discharge for every four (4) hours for three days. Each discharge lasts for 13 minutes at a release rate of $10 \mathrm{gpm}$. The only difference between Cases 7 and 8 is the concentration of the tritiated waste water. The concentration of the tritiated waste water for Case 7 is 10 $\mu \mathrm{Ci} / \mathrm{ml}$, and for Case 8 is $5 \mu \mathrm{Ci} / \mathrm{ml}$. The calculated peak tritium concentration in Savannah River at US Highway 301 is $2.6 \mathrm{pCi} / \mathrm{ml}$ for Case 7 , and $1.3 \mathrm{pCi} / \mathrm{ml}$ for Case 8 , as listed in Table 3 and shown by Figure 5. Figure 5 shows that the calculated concentrations start to decrease after 120 hours. The reason is that the simulation assumes that the Rework Distillate Tanks stop releasing tritiated waste water after day three.

\section{Discharge from DW Facility Distillate Tanks}

The DW Facility distillate tanks discharge once per week at a release rate of $25 \mathrm{gpm}$ and a release duration of 63 minutes. The maximum tritium concentration of the discharge waste water is $1.0 \mu \mathrm{Ci} / \mathrm{ml}$ and the nominal concentration is less than $1.0 \mu \mathrm{Ci} / \mathrm{ml}$. The calculated peak tritium concentrations in Savannah River at US Highway 301 are 1.1 and $0.57 \mathrm{pCi} / \mathrm{ml}$ for tritiated waste water concentrations of 1.0 and $0.5 \mu \mathrm{Ci} / \mathrm{ml}$, respectively, as listed in Table 3 and shown by Figure 6.

\section{Concurrent Releases}

Four cases (listed in Table 3) were studied to simulate different combination of concurrent releases from the Drum Wash, Rework and DW facilities. In Cases 11 and 12, all facilities discharge with the maximum tritiated waste water concentration. In Cases 13 and 14 , all facilities discharge with a nominal tritiated waste water concentration. Table 3 and Figure 7 list release rates and durations for these cases. The maximum peak concentration for these concurrent release combinations was calculated to be $18.0 \mathrm{pCi} / \mathrm{ml}$ for Case 12 , and the minimum peak concentration was calculated to be $4.0 \mathrm{pCi} / \mathrm{ml}$ for Case 13.

\section{Minimize Downstream Tritium Concentrations}

For the D-Area Heavy Water Facilities, the Drum Wash Waste Tanks contribute the most of the downstream tritium concentrations, as shown in Table 3. One can minimize the tritium concentration in the Savannah River at U.S. Highway 301 by modifying the Drum Wash Waste Tanks release procedures. Additional cases simulated assume that the Drum Wash Waste Tanks are operating at a batch release mode. The release of each batch lasts 120 or 240 minutes, and the frequency of release is once per day. Case $5 \mathrm{C}$ is a modification of Case 5. Case $5 \mathrm{C}$ assumes that the Drum Wash Waste Tanks is in a batch release mode. Each release lasts 240 minutes. The release rate is $5 \mathrm{gpm}$ and the discharge concentration of the tritiated waste water is $3.5 \mu \mathrm{Ci} / \mathrm{ml}$. It will take 14 days to empty the Drum Wash Waste Tank inventory of 16,000 gallon. The calculated peak concentration in the Savannah River at U.S. Highway 301 for Case $5 \mathrm{C}$ is $2.9 \mathrm{pCi} / \mathrm{ml}$. 
There is a significant reduction in the calculated tritium concentration from Case $5,7.7$ $\mathrm{pCi} / \mathrm{ml}$, to Case $5 \mathrm{C}, 2.9 \mathrm{pCi} / \mathrm{ml}$, as shown in Figure 4 and Table 3 . There are only three peaks shown in Figure 4 for Cases $5 \mathrm{C}$. The reason of this is that the batch release of the Drum Wash Waste Tank was simulated for 3 days to show the typical tritium concentration downstream.

Case $6 \mathrm{C}$ is a modification of Case 6 . The difference between Case 6 and Case $6 \mathrm{C}$ is that Case 6 releases twice per month, and each release lasts for 1600 minutes. Case $6 \mathrm{C}$ is in a batch mode. Each batch release lasts 120 minutes. It will take 14 days to empty the Drum Wash Waste Tank inventory of 16,000 gallon. The calculated peak concentration in the Savannah River at U.S. Highway 301 for Case $6 \mathrm{C}$ is $2.9 \mathrm{pCi} / \mathrm{ml}$. There is a significant reduction in the calculated tritium concentration from Case $6,15.5 \mathrm{pCi} / \mathrm{ml}$, to Case $6 \mathrm{C}, 2.9 \mathrm{pCi} / \mathrm{ml}$, as shown in Figure 4 and Table 3 . There are only three peaks shown in Figure 4 for Cases $6 \mathrm{C}$. The reason of this is that the batch release of the Drum Wash Waste Tank was simulated for 3 days to show the typical tritium concentration downstream.

For concurrent releases, Case $11 \mathrm{C}$ is a modification of Case 11 . The difference between Cases 11 and $11 \mathrm{C}$ is the release pattern for Drum Wash Waste Tanks. For Case 11, the Drum Wash Waste Tanks release twice per month, and each release lasts for 3200 minutes. For Case $11 \mathrm{C}$, the Drum Wash Waste Tank is in a batch release mode as described in Case 5C. The calculated peak concentration in the Savannah River at U.S. Highway 301 for Case $11 \mathrm{C}$ is $5.9 \mathrm{pCi} / \mathrm{ml}$. There is a significant reduction in the calculated tritium concentration from Case $11,10.3 \mathrm{pCi} / \mathrm{ml}$, to Case $11 \mathrm{C}, 5.9 \mathrm{pCi} / \mathrm{ml}$, as shown in Figure 8.

Case $12 \mathrm{C}$ is a modification of Case 12. The difference between Cases 12 and $12 \mathrm{C}$ is the release pattern for Drum Wash Waste Tanks. For Case 12, the Drum Wash Waste Tanks release twice per month, and each release lasts for 3200 minutes. For Case $12 \mathrm{C}$, the Drum Wash Waste Tanks are in batch release mode as described in Case $6 \mathrm{C}$. The calculated peak concentration in the Savannah River at U.S. Highway 301 for Case $12 \mathrm{C}$ is $6.063 \mathrm{pCi} / \mathrm{ml}$. There is a significant reduction in the calculated tritium concentration from Case $12,18.0 \mathrm{pCi} / \mathrm{ml}$, to Case $12 \mathrm{C}, 6.063 \mathrm{pCi} / \mathrm{ml}$, as shown in Figure 8 . It will take 14 days for Cases $11 \mathrm{C}$ and $12 \mathrm{C}$ to empty the Drum Wash Waste Tank inventory of 16,000 gallon. There are only three peaks shown in Figure 8 for Cases $11 \mathrm{C}$ and $12 \mathrm{C}$. The reason of this is that the batch release of the Drum Wash Waste Tank was simulated for 3 days to show the typical tritium concentration downstream. 


\section{CONCLUSIONS}

The contributions of the D-Area Heavy Water Facilities tritium releases to the tritium concentration in the Savannah River have been analyzed. The U.S. EPA WASP5 computer code was used to simulate surface water transport for tritium releases from the D-Area Drum Wash, Rework and DW facilities. The WASP5 model was qualified with the 1993 tritium measurements at U.S. Highway 301. At the maximum tritiated waste water concentrations, the calculated tritium concentration in the Savannah River at U.S. Highway 301 due to concurrent releases from D-Area Heavy Water Facilities varies from 5.9 to $18.0 \mathrm{pCi} / \mathrm{ml}$ as a function of the operation conditions of these facilities. The calculated concentration becomes the lowest when the batch releases method for the Drum Wash Waste Tanks is adopted. 


\section{REFERENCES:}

1. D. W. Hayes, "Predicted Peak Tritium Concentrations at Highway 301 for Planned Aqueous Releases from SRS Facilities," SRT-ETS-920123, June 6, 1992.

2. "Environmental Release Prevention and Control Plan (ERP\&CP)," WSR-92067, June $30,1992$.

3. J. J. Shake, "Technical Assistance Request: Surface Water Modeling Using an EPA Computer Code for Tritiated Water Discharges from the Heavy Water Facility," July 27, 1995.

4. Ambrose, Robert B., Wool, Tim A. and Martin, James L., "The Water Quality Analysis Simulation Program, WASP5, Part A: Model Documentation; Part B: Input Data Set," Environmental Research Laboratory, Office of Research and Development, U.S. Environmental Protection Agency, Athens, Georgia, September 20, 1993.

5. Arnett, Margaret W., "Savannah River Site Environmental Data for 1993," WSRC-TR94-077.

6. "Water Resources Data South Carolina Water Year 1993," U.S. Geological Survey Water-Data Report SC-93-1.

7. "Water Resources Data South Carolina Water Year 1994," U.S. Geological Survey Water-Data Report SC-94-1. 
Table 1

Specified Input Conditions

DW Distillate $\quad \underline{\text { RW Distillate }}$ Drum Wash Tank

Capacity (gal)

Discharge Rate (gpm)

Max. $\mathrm{H}^{3}$ Concentration $(\mu \mathrm{Ci} / \mathrm{ml})$

Nominal $\mathrm{H}^{3}$ Acitivity $(\mu \mathrm{Ci} / \mathrm{ml})$

Release Duration (min.)

Discharge Frequency (avg.)

* Batch release
1565.0

25.0

1.0

$<1.0$

63.0

$1 /$ week
125.0

10.0

10.0

$<5.0$

13.0

6/day
16000.0

$5.0-10.0$

3.5

1.25

$3200.0^{*}$

2/month 
Table 2

Estimated Tritium Releases in SRS Streams and the Savannah River

Page 1 of 3

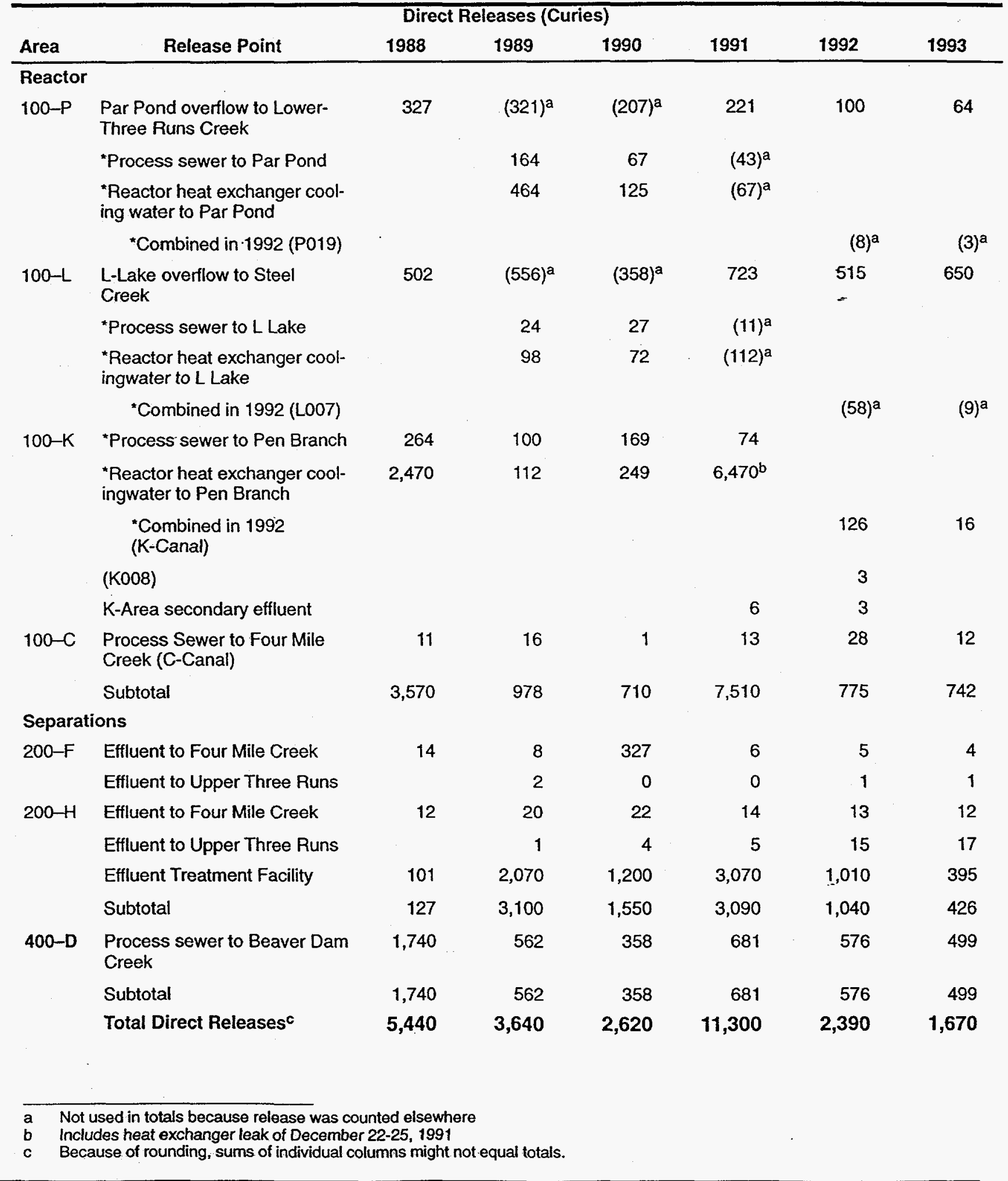


Table 2

Estimated Tritium Releases in SRS Streams and the Savannah River

Page 2 of 3

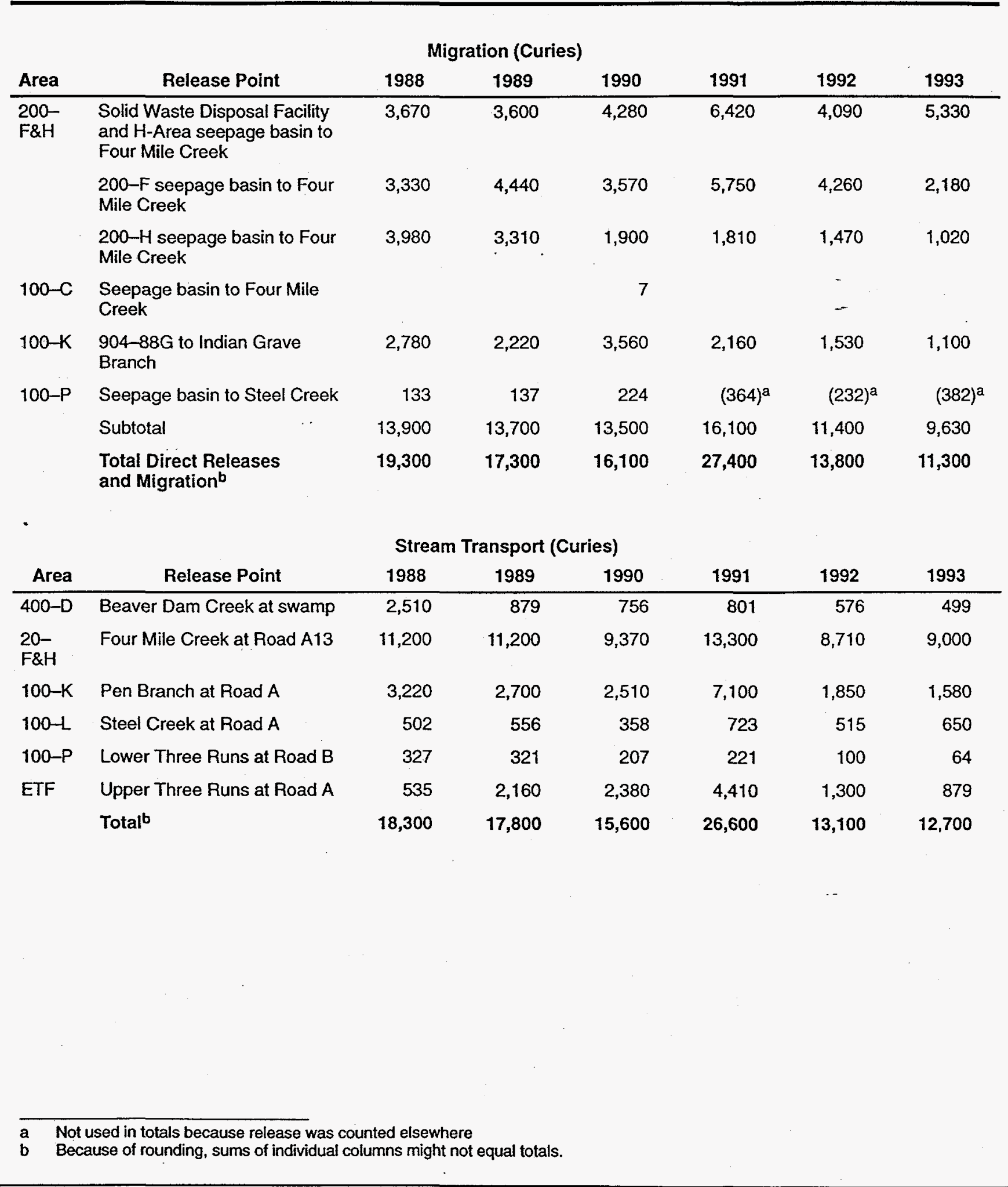


WSRC-TR-98-00230

June 1998

Table 2

Estimated Tritium Releases in SRS Streams and the Savannah River

Page 3 of 3

\begin{tabular}{|c|c|c|c|c|c|c|}
\hline \multicolumn{7}{|c|}{ River Transport (Curies) } \\
\hline & 1988 & 1989 & 1990 & 1991 & 1992 & 1993 \\
\hline $\begin{array}{l}\text { Tritium measured in the Savannah River } \\
\text { below SRS }\end{array}$ & & 17,110 & 16,570 & 28,700 & 16,000 & 12,600 \\
\hline $\begin{array}{l}\text { Tritium measured in the Savannah River } \\
\text { above SRS }\end{array}$ & & 1,480 & 2,080 & 2,420 & 2,210 & 433 \\
\hline $\begin{array}{l}\text { Tritium measured in the Savannah } \\
\text { River below SRS (downriver minus } \\
\text { upriver)a }\end{array}$ & 14,600 & 15,600 & 14,490 & 26,300 & 13,800 & 12,200 \\
\hline
\end{tabular}


Table 3

WASP5 Calculations of Peak Tritium Concentrations in the Savannah River at U.S. Highway 301 due to Tritiated Liquid Waste Releases from the D-Area Heavy Water Facilities

Discharge from Drum Wash Waste Tank

Case $\quad \mathrm{H}^{3}$ Concentration in the Waste Water

$\mu \mathrm{Ci} / \mathrm{ml}$

1.25

1.25

3.4

3.4

3.5

3.5

3.5

3.5
Release

Rate Duration
gpm $\min$.

5

5
10

10

5

10

5

5

10

10
3200

1600

3200

1600

3200

240

1600

120
Calculated $\mathrm{H}^{3}$ at US Hwy 301

$\mathrm{pCi} / \mathrm{ml}$

2.8

5.5

7.5

15.0

7.7

2.9

15.5

2.9

Discharge from Rework Distillate Tank

Case $\quad \mathrm{H}^{3}$ Concentration in the Waste Water

$\mu \mathrm{Ci} / \mathrm{ml}$

7

8

10

5
Release

Rate Duration Frequency

gpm $\min$.

10

10
13

13
Calculated $\mathrm{H}^{3}$ at US Hwy 301

$\mathrm{pCi} / \mathrm{ml}$

\section{6}

1.3

Discharge from DW Distillate Tank

Case $\quad \mathrm{H}^{3}$ Concentration in the Waste Water

$\mu \mathrm{Ci} / \mathrm{ml}$

9

10
1

0.5
Release

\begin{tabular}{lcc} 
& Release \\
\hline Rate & Duration & Frequency \\
gpm & min. &
\end{tabular}

25

25
63

63
Calculated $\mathrm{H}^{3}$ at US Hwy 301

$\mathrm{pCi} / \mathrm{ml}$

1.1

0.57 
Table 3 (Cont'd)

WASP5 Calculations of Peak Tritium Concentrations in the Savannah River at U.S. Highway 301 due to Tritiated Liquid Waste Releases from the D-Area Heavy Water Facilities

Concurrent Discharge from Drum Wash, Rework and DW Facilities

$$
\begin{array}{r}
\mathrm{H}^{3} \text { Concentration } \\
\text { in the Waste Water } \\
\mu \mathrm{Ci} / \mathrm{ml}
\end{array}
$$

\begin{tabular}{lcc}
\multicolumn{3}{c}{ Release } \\
\hline Rate & Duration & Frequency \\
gpm & min. &
\end{tabular}

Case 11

Rework

Drum Wash

DW
10

3.5

1.0
10

5

25

$\begin{array}{rl}13 & 6 / \text { day } \\ 3200 & 2 / \text { month } \\ 63 & 1 / \text { week }\end{array}$

Calculated $\mathrm{H}^{3}$ Concentration at US HWY $301(\mathrm{pCi} / \mathrm{ml})$

Case 11C

Rework

Drum Wash

10

DW

10

5

25

$\begin{array}{rl}240 & 1 / \text { day } \\ 63 & 1 / \text { week }\end{array}$

Calculated $\mathrm{H}^{3}$ Concentration at US HWY $301(\mathrm{pCi} / \mathrm{ml})$

Case 12

Rework

Drum Wash

10

DW

10

10

1.0

25

$\begin{array}{rl}1600 & 2 / \text { month } \\ 63 & 1 / \text { week }\end{array}$

Calculated $\mathrm{H}^{3}$ Concentration at US HWY $301(\mathrm{pCi} / \mathrm{ml})$

18.0

Case 12C

Rework

Drum Wash

10

DW

3.5

10

10

1.0

25

Calculated $\mathrm{H}^{3}$ Concentration at US HWY $301(\mathrm{pCi} / \mathrm{ml})$

$\begin{array}{rl}120 & 1 / \text { day } \\ 63 & 1 / \text { week }\end{array}$

Case 13

Rework

Drum Wash

5

DW

10

5

25

Calculated $\mathrm{H}^{3}$ Concentration at US HWY $301(\mathrm{pCi} / \mathrm{ml})$

Case 14

Rework

Drum Wash

5
1.25
0.5

10

DW

0.5

10

25

Calculated $\mathrm{H}^{3}$ Concentration at US HWY $301(\mathrm{pCi} / \mathrm{ml})$

$\begin{array}{rl}3200 & \text { 6/day } \\ 63 & 1 / \text { month } \\ & 1 / \text { week }\end{array}$

$\begin{array}{rl}13 & 6 / \text { day } \\ 1600 & 2 / \text { month } \\ 63 & 1 / \text { week }\end{array}$

6.8 
Figure 1

Savannah River

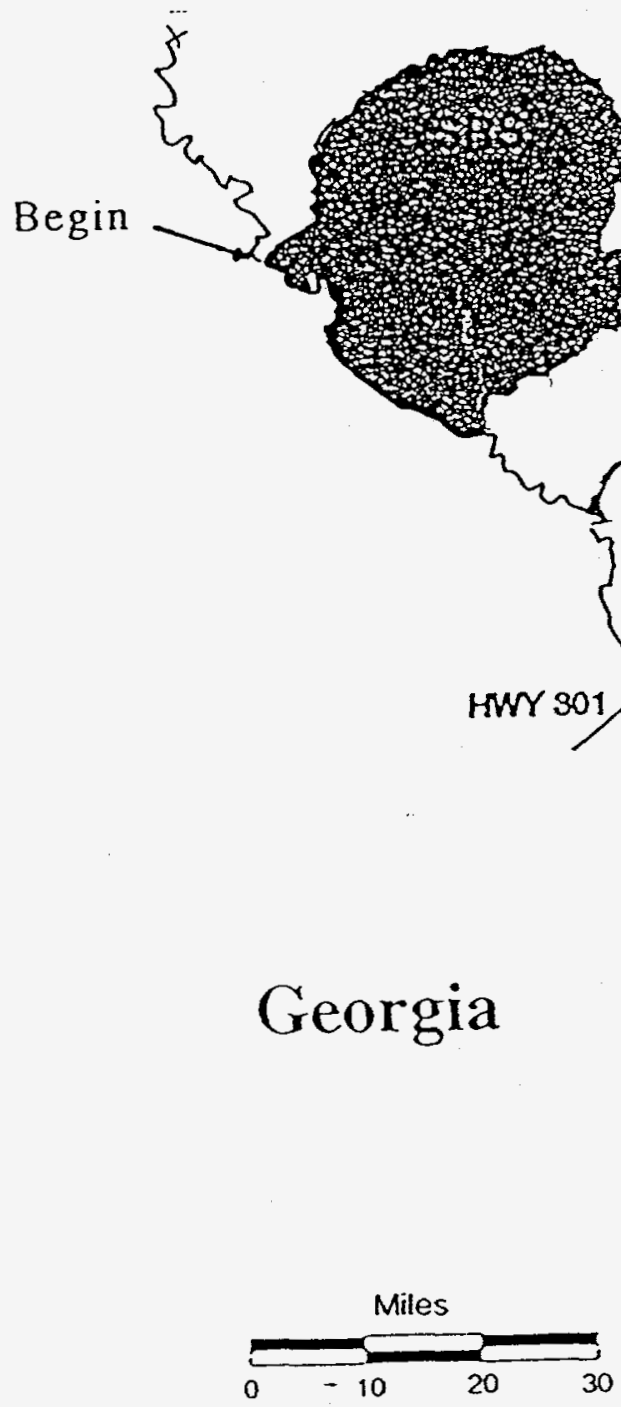

Allendalo

\section{South Carolina}
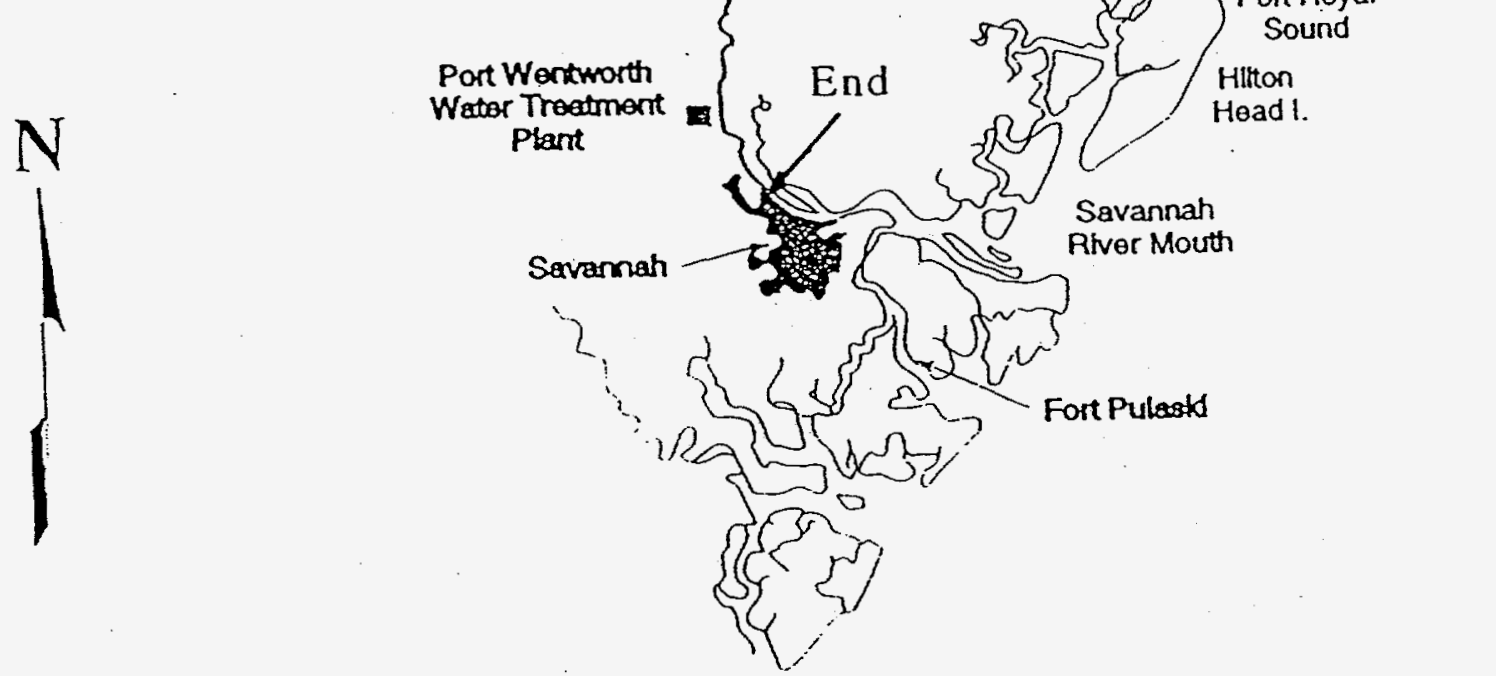
Figure 2

Beaver Dam Creek

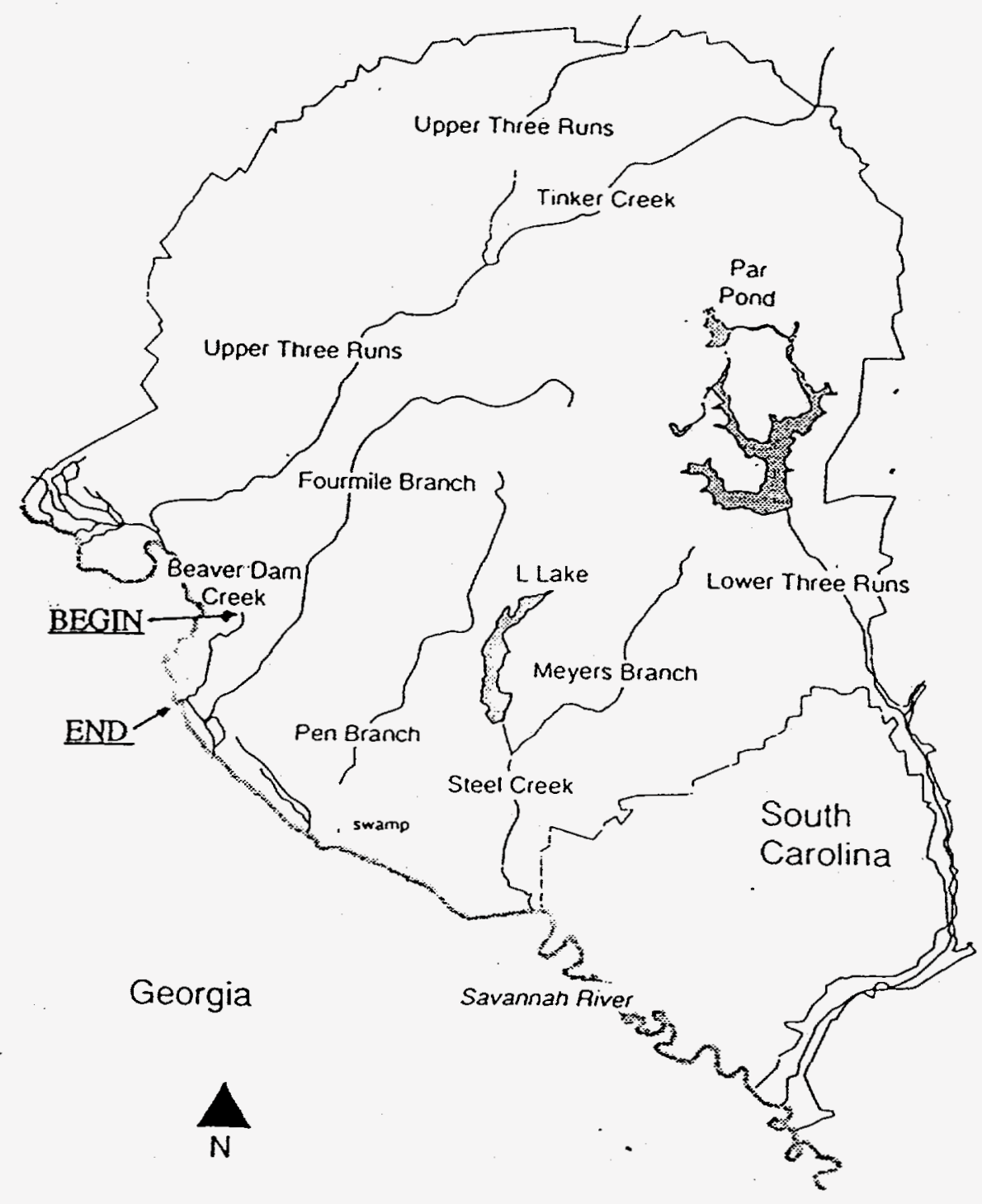

$\stackrel{0}{0} \frac{2}{\text { Scale in Miles }}$

0
-24

Scale in Kilometers 
Figure 3

WASP5 Calculations of Tritium Concentrations in the Savannah River at U.S. Highway 301, due to D-Area Drum Wash Waste Tanks Releases

$\begin{array}{cc}\text { Case } & \begin{array}{c}\mathrm{H}^{3} \text { Concentration } \\ \text { in the Waste Water }\end{array} \\ & \mu \mathrm{Ci} / \mathrm{ml} \\ 1 & 1.25 \\ 2 & 1.25 \\ 3 & 3.4 \\ 4 & 3.4\end{array}$

\begin{tabular}{|c|c|c|}
\hline & Release & \\
\hline $\begin{array}{l}\text { Rate } \\
\text { gpm }\end{array}$ & $\begin{array}{r}\text { Duration } \\
\text { min. }\end{array}$ & Frequency \\
\hline 5 & 3200 & $2 /$ month \\
\hline 10 & 1600 & $2 /$ month \\
\hline 5 & 3200 & $2 /$ month \\
\hline 10 & 1600 & $2 /$ month \\
\hline
\end{tabular}

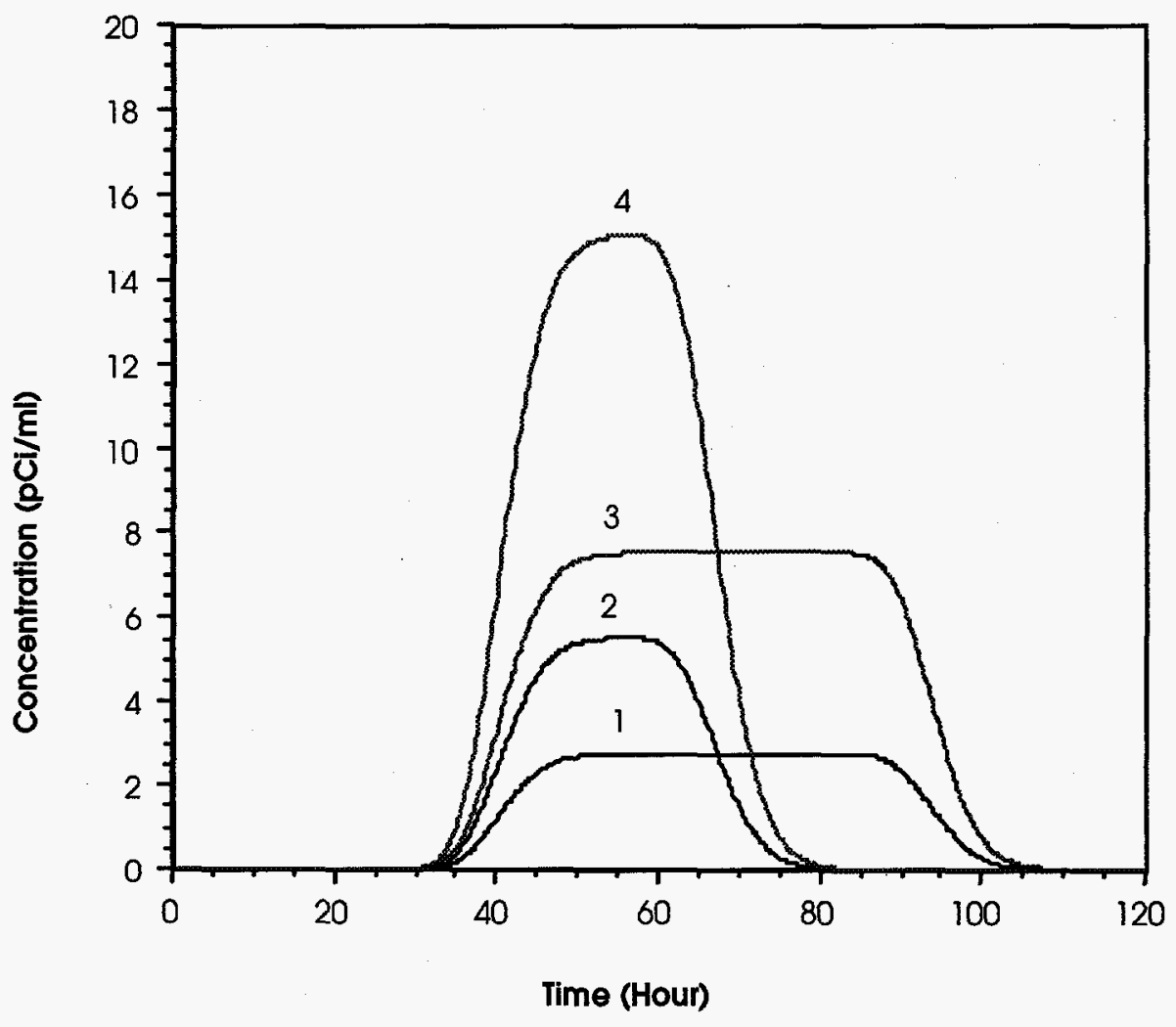


WSRC-TR-98-00230

\section{June 1998}

Figure 4

WASP5 Calculations of Tritium Concentrations in the Savannah River at U.S. Highway 301 due to D-Area Drum Wash Waste Tanks Releases

\begin{tabular}{|c|c|c|c|c|}
\hline \multirow[t]{2}{*}{ Case } & \multirow{2}{*}{$\begin{array}{c}\mathrm{H}^{3} \text { Concentration } \\
\text { in the Waste Water } \\
\mu \mathrm{Ci} / \mathrm{ml}\end{array}$} & \multicolumn{3}{|c|}{ Release } \\
\hline & & $\begin{array}{l}\text { Rate } \\
\text { gpm }\end{array}$ & $\begin{array}{c}\text { Duration } \\
\text { min. }\end{array}$ & Frequency \\
\hline 5 & 3.5 & 5 & 3200 & $2 /$ month \\
\hline $5 \mathrm{C}$ & 3.5 & 5 & 240 & 1/day \\
\hline 6 & 3.5 & 10 & 1600 & 2/month \\
\hline $6 C$ & 3.5 & 10 & 120 & 1/day \\
\hline
\end{tabular}

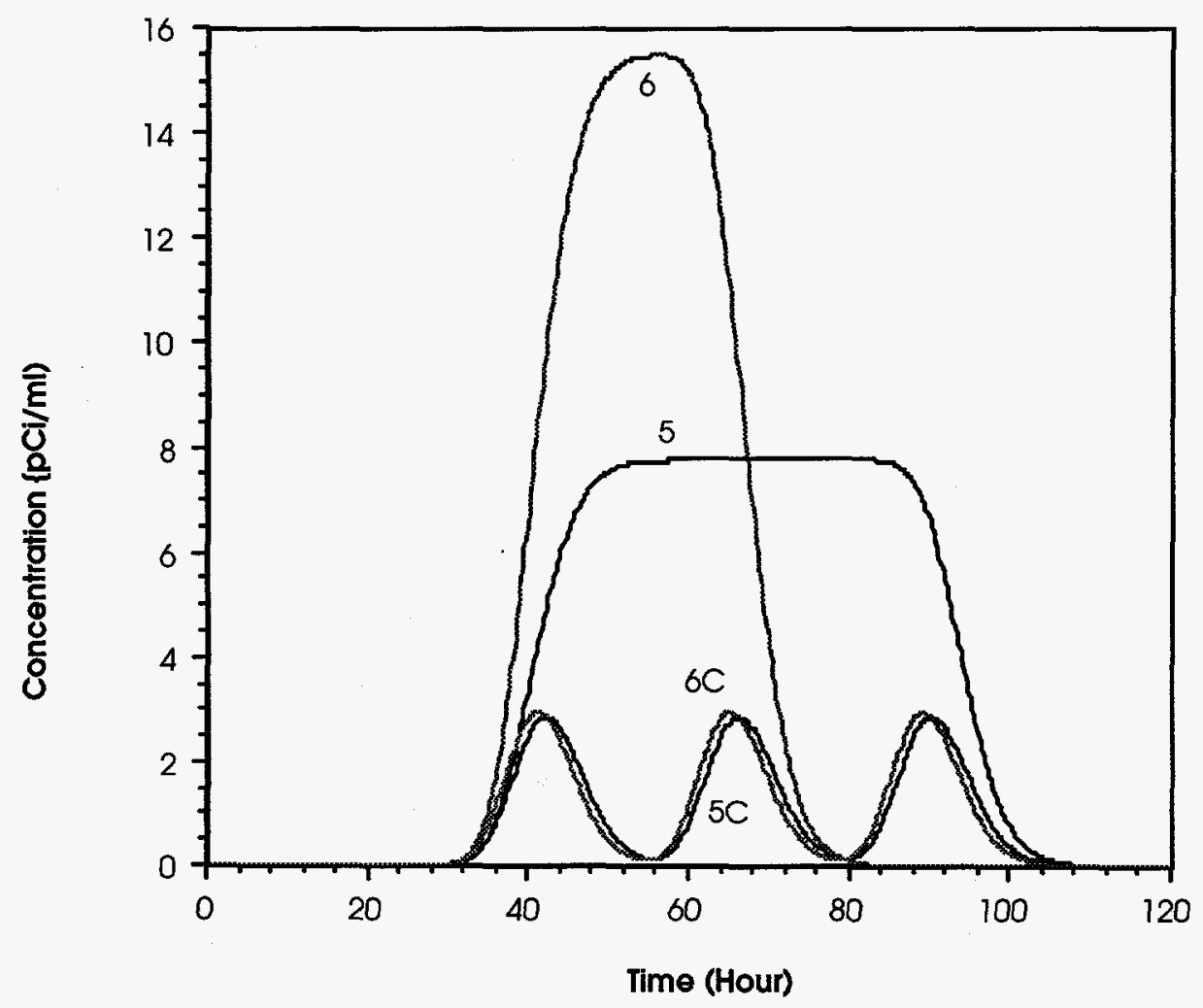


Figure 5

WASP5 Calculations of Tritium Concentrations in the Savannah River at U.S. Highway 301 due to D-Area Rework Distillate Tanks Releases

$\begin{array}{ccccc}\text { Case } & \begin{array}{c}\mathrm{H}^{3} \text { Concentration } \\ \text { in the Waste Water } \\ \mu \mathrm{Ci} / \mathrm{ml}\end{array} & \begin{array}{c}\text { Rate } \\ \mathrm{gpm}\end{array} & \begin{array}{c}\text { Duration } \\ \text { min. }\end{array} & \text { Frequency } \\ 7 & 10 & 10 & 13 & 6 / \text { day } \\ 8 & 5 & 10 & 13 & 6 / \text { day }\end{array}$

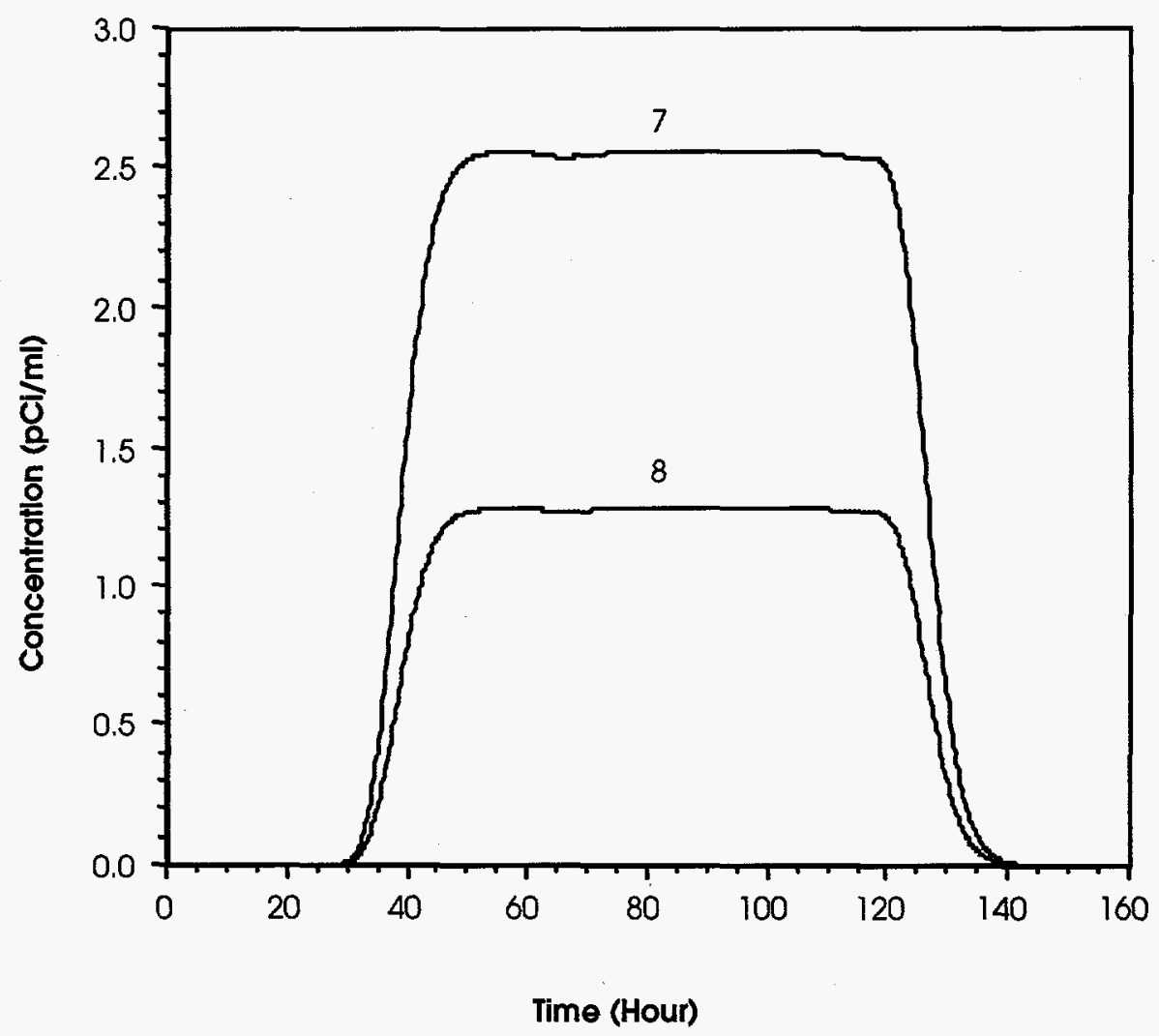


Figure 6

WASP5 Calculations of Tritium Concentrations in the Savannah River at U.S. Highway 301 due to D-Area DuPont Water Distillate Tanks Releases

\begin{tabular}{|c|c|c|c|c|}
\hline \multirow[t]{2}{*}{ Case } & \multirow{2}{*}{$\begin{array}{c}\mathrm{H}^{3} \text { Concentration } \\
\text { in the Waste Water } \\
\mu \mathrm{Ci} / \mathrm{ml}\end{array}$} & \multicolumn{3}{|c|}{ Release } \\
\hline & & $\begin{array}{l}\text { Rate } \\
\text { gpm }\end{array}$ & $\begin{array}{c}\text { Duration } \\
\text { min. }\end{array}$ & Frequency \\
\hline 9 & 1.0 & 25 & 63 & 1/week \\
\hline 10 & 0.5 & 25 & 63 & $1 /$ week \\
\hline
\end{tabular}

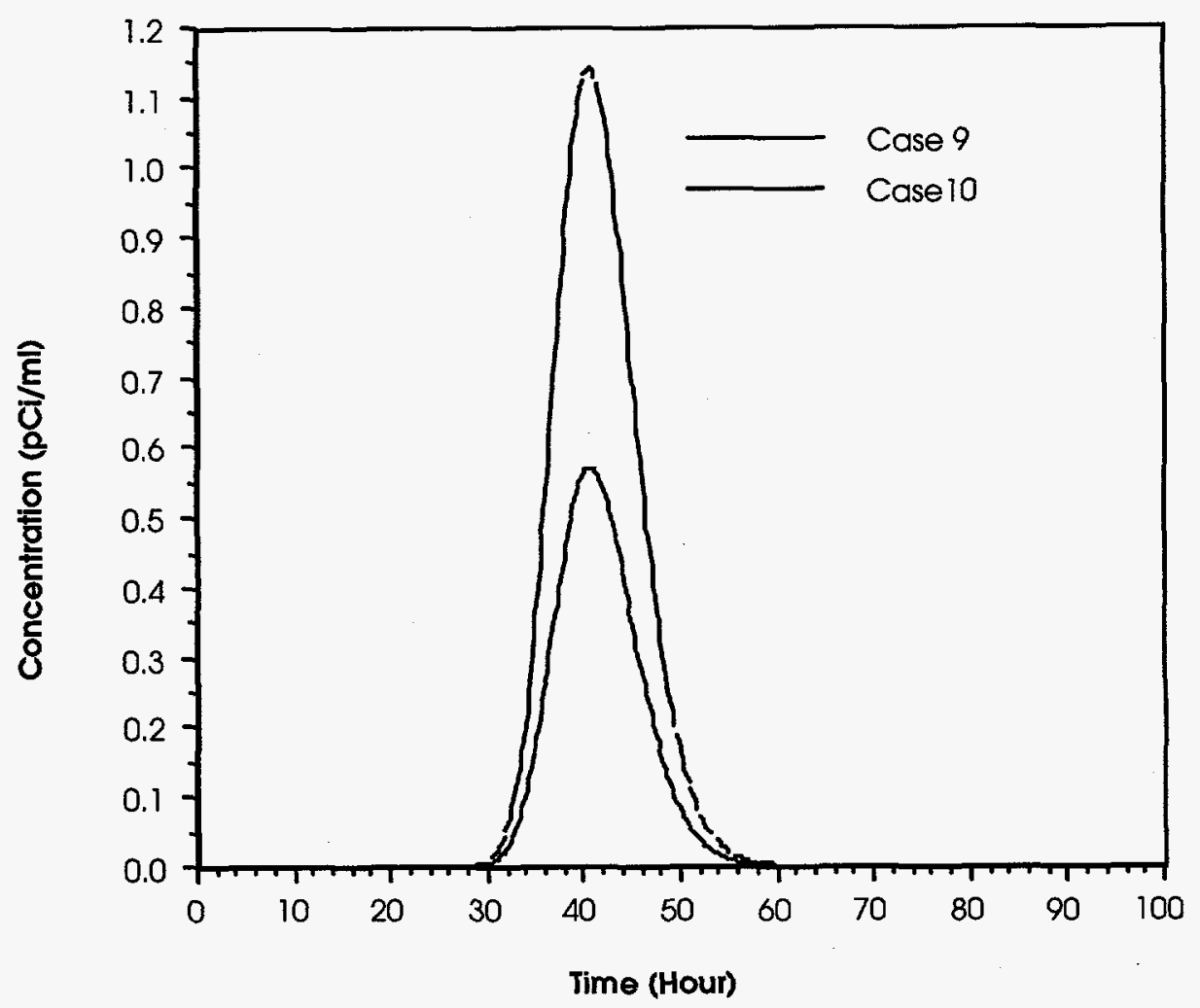


Figure 7

WASP5 Calculations of Tritium Concentrations in the Savannah River at U.S. Highway 301 due to Concurrent Releases from the D-Area Heavy Water Facilities

Case 11

Rework

Drum Wash

DW

$\mathrm{H}^{3}$ Concentration

in the Waste Water

$\mu \mathrm{Ci} / \mathrm{ml}$

Case 12

Rework

Drum Wash

DW

Case 13

Rework

Drum Wash

DW

Case 14

Rework

Drum Wash

DW

10
3.5
1.0

10
3.5
1.0

5
1.25
0.5

5
1.25
0.5

10

1.0

10

3.5

1.0

5

1.25

0.5

5

1.25

0.5

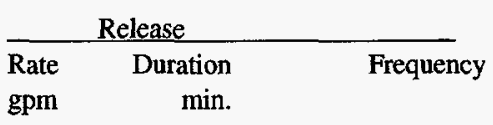

10

5

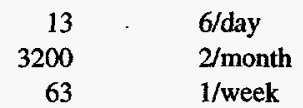

25

$\begin{array}{rl}13 & 6 / \text { day } \\ 1600 & 2 / \text { month } \\ 63 & 1 / \text { week }\end{array}$

25

$\begin{array}{rl}13 & 6 / \text { day } \\ 3200 & 2 / \text { month } \\ 63 & 1 / \text { week }\end{array}$

25

$\begin{array}{rl}13 & 6 / \text { day } \\ 1600 & 2 / \text { month } \\ 63 & 1 / \text { week }\end{array}$

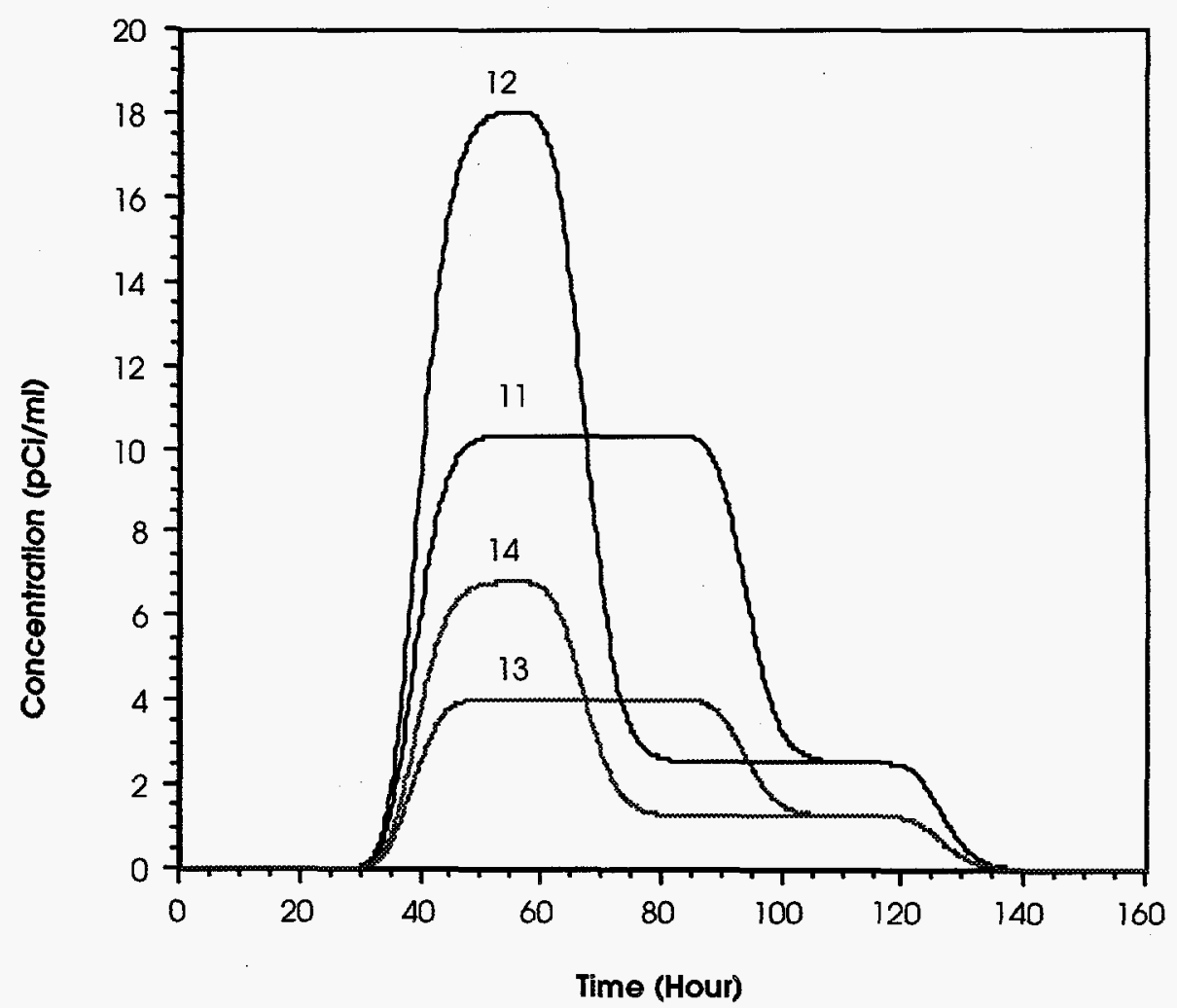




\section{June 1998}

Figure 8

WASP5 Calculations of Tritium Concentrations in the Savannah River at U.S. Highway 301 due to Concurrent Releases from the D-Area Heavy Water Facilities

\begin{tabular}{|c|c|c|c|c|}
\hline \multirow{2}{*}{\multicolumn{2}{|c|}{$\begin{array}{c}\mathrm{H}^{3} \text { Concentration } \\
\text { in the Waste Water } \\
\mu \mathrm{Ci} / \mathrm{ml}\end{array}$}} & \multicolumn{3}{|c|}{ Release } \\
\hline & & $\begin{array}{l}\text { Rate } \\
\text { gpm }\end{array}$ & $\begin{array}{c}\text { Duration } \\
\text { min. }\end{array}$ & Frequency \\
\hline \multicolumn{5}{|c|}{ Case 11} \\
\hline Rework & 10 & 10 & 13 & $6 /$ day \\
\hline Drum Wash & 3.5 & 5 & 3200 & $2 /$ month \\
\hline DW & 1.0 & 25 & 63 & 1/week \\
\hline \multicolumn{5}{|l|}{ Case 11C } \\
\hline Rework & 10 & 10 & 13 & 6/day \\
\hline Drum Wash & 3.5 & 5 & 240 & 1/day \\
\hline DW & 1.0 & 25 & 63 & 1/week \\
\hline \multicolumn{5}{|l|}{ Case 12} \\
\hline Rework & 10 & 10 & 13 & 6/day \\
\hline Drum Wash & 3.5 & 10 & 1600 & $2 /$ month \\
\hline DW & 1.0 & 25 & 63 & $1 /$ week \\
\hline \multicolumn{5}{|l|}{ Case 12C } \\
\hline Rework & 10 & 10 & 13 & 6/day \\
\hline Drum Wash & 3.5 & 10 & 120 & $1 /$ day \\
\hline DW & 1.0 & 25 & 63 & $1 /$ week \\
\hline
\end{tabular}

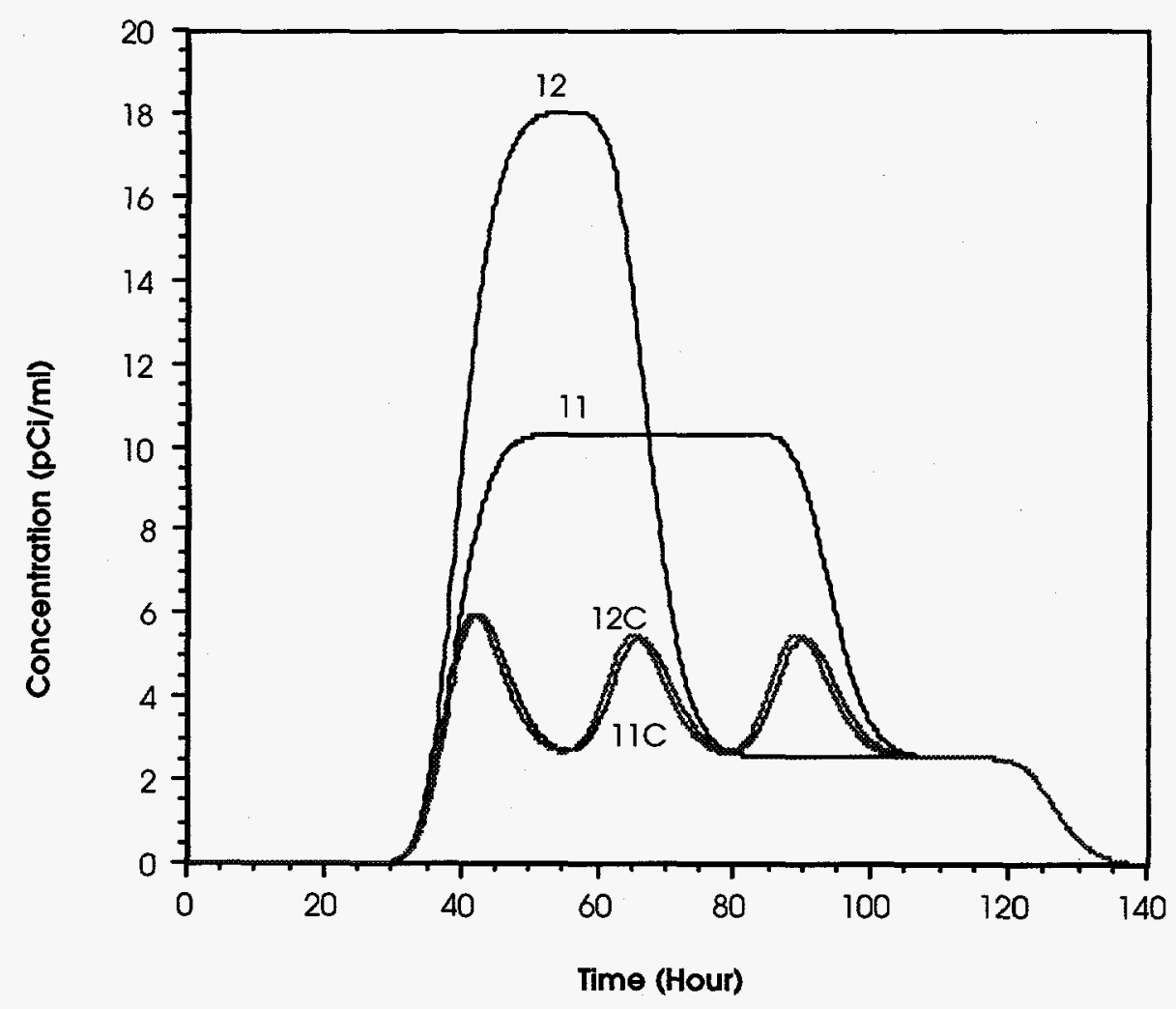


WSRC-TR-98-00230

June 1998

WESTINGHOUSE SAVANNAH RIVER CO.

Report WSRC-TR-98-00230

DISTRIBUTION

SAVANNAH RIVER SITE
A. L. Boni, 773-A
R. P. Addis, 773-A
D. P. Griggs, 773-A
Kuo-Fu Chen, 773-A
SRTC Records (4), 773-52A
NTS Records (5), 773-A 